\title{
MAKANAN DAN MINUMAN DALAM ISLAM
}

\author{
Nilda Miftahul Janna ${ }^{1}$ Aisma $^{2}$, Muhammad Arsyam ${ }^{3}$ \\ ${ }^{1}$ Sekolah Tinggi Agama Islam (STAI) Darul Dakwah Wal-Irsyad (DDI) Kota Makassar, Indonesia \\ Email: nildamiftahuljanna@gmail.com \\ ${ }^{2}$ Sekolah Tinggi Agama Islam (STAI) Darul Dakwah Wal-Irsyad (DDI) Kota Makassar, Indonesia \\ Email: aisma069@gmail.com \\ ${ }^{3}$ Sekolah Tinggi Agama Islam (STAI) Darul Dakwah Wal-Irsyad (DDI) Kota Makassar, Indonesia \\ Email: arsyam0505@gmail.com
}

\begin{abstract}
ABSTRAK
Perintah untuk mengkonsumsi makanan dan minuman halal telah jelas terdapat di kedua sumber rujukan bagi umat Islam, yaitu Al-Qur'an dan Hadis. Namun kenyataannya umat Islam di Indonesia khususnya belum memiliki kesadaran yang tinggi menyangkut makanan dan minuman halal. Padahal apa yang masuk dalam darah daging seorang muslim akan berpengaruh pada perilaku mereka dalam keseharian. Sesungguhnya di dalam tubuh manusia itu ada segumpal daging, apabila ia baik maka baiklah seluruh tubuhnya dan jikalau ia rusak, maka rusaklah seluruh tubuhnya. tidak lain dan tidak bukan itulah yang dikatakan hati. Segala sesuatu yang Allah tidak melarangnya berarti halal, dengan demikian semua makanan dan minuman di luar yang di haramkan adalah halal.
\end{abstract}

Kata Kunci : Makanan, Minuman, Dalam, Islam

\section{A. PENDAHULUAN}

Sebagai seorang muslim yang ingin mendekatkan diri, atau berusaha untuk taat kepada Allah Sang Maha Pencipta, tentulah kita harus menjalankan ibadah kepada Allah, baik itu yang wajib maupun yang sunnah agar Allah ridho kepada kita. Namun ada hal lain yang tak boleh kita abaikan dalam usaha memperoleh ridho Allah, yaitu makanan dan minuman.

Dalam Islam halal dan haram telah ditentukan dengan jelas, banyak sekali ayat AlQur'an dan Al-Hadis yang membahas hal tersebut. Dengan demikian, mengkonsumsi makanan dan minuman yang halal merupakan suatu kewajiban bagi umat Islam.

Apabila makanan dan minuman kita terjaga dari yang diharamkan Allah, atau dengan kata lain kita hanya makan atau mengkonsumsi yang dihalalkan Allah, niscaya ridho Allah itu tidak mustahil kita peroleh jika kita taat kepada-Nya. Tetapi sebaliknya, meskipun kita taat, namun kita makan dan minum dari yang haram yang bukan karena udah, maka akan sia-sialah usaha kita. Untuk itu, makalah ini disusun untuk mengupas tentang makanan dan minuman yang halal dan yang haram dalam Islam.

\section{B. PEMBAHASAN}

\section{Pengertian Makanan Dan Minuman}

\section{1) Pengertian Makanan}

Secara etimologi makan berarti memasukkan sesuatu melalui mulut, sedangkan makanan ialah segala sesuatu yang boleh dimakan. Dalam bahasa arab makanan berasal dari kata al-tha'am dan jamaknya Al-Atimah yang artinya makan makanan. Sedangkan 
dalam ensiklopedi hukum Islam makanan ialah segala sesuatu yang boleh dimakan oleh manusia atau sesuatu yang menghilangkan lapar.

Sedangkan pengertian makanan menurut istilah adalah apa saja yang dimakan oleh manusia dan disantap, baik berupa barang pangan, maupun yang lainnya. Penggunaan kata tha'am dalam al-Qur'an bersifat umum, yakni setiap yang dapat dimakan, baik makanan itu berasal dari darat dan laut, maupun makanan yang belum diketahui hakikatnya. Dengan demikian kata al-tha'am makanan, adalah menunjukan arti semua jenis yang biasa dicicipi (makanan dan minuman). Makanan menurut al-Qur'an, ada yang halal dan ada yang haram.

Makanan merupakan sumber protein yang berguna bagai manusia, yang berasal dari hewan disebut protein hewani dan yang berasal dari tumbuh-tumbuhan disebut protein nabati. Semuanya merupakan karunia Allah kepada manusia. Oleh karena itu Islam tidak melarang manusia baik laki-laki maupun wanita untuk menikmati kehidupan dunia, seperti makanan dan minuman, sesuai dengan firman Allah Swt dalam Surah al 'Araf ayat 31: Artinya : "Wahai anak cucu Adam! Pakailah pakaianmu yang bagus pada setiap (memasuki) masjid, makan dan minumlah, tetapi jangan berlebihan. Sesungguhnya, Allah tidak menyukai orang yang berlebihan".

\section{2) Pengertian Minuman}

Minum secara etimologi berarti meneguk barang cair dengan mulut, sedangkan minuman adalah segala sesuatu yang boleh di minum. Dalam bahasa arab minuman berasal dari kata al-asyribah dan jamaknya al-syarb yang artinya minum minuman. Sedangkan dalam ensiklopedi hukum islam diartikan dengan jenis air atau zat cair yang bisa diminum.

Secara terminologi, kata syarab berarti sesuatu yang diminum, baik berupa air biasa, maupun air yang sudah melalui proses pengolahan, yang sudah berubah warna dan rasanya. Dalam al-Qur'an kata syarab digunakan dengan makna yang sama, baik dalam konteks minuman dunia, maupun minuman akhirat. Dalam kedua konteks ini dipahami, bahwa pada dasarnya maksud syarab atau minuman, adalah makna lafzhi, yaitu benarbenar minuman.

Dari uraian tentang pengertian makanan dan minuman, dapat disimpulkan, bahwa di antara makanan dan minuman baik yang berasal dari tumbuh-tumbuhan, maupun dari hewan sudah ada ketetapan hukumnya, yaitu ada yang dihalalkan dan ada yang diharamkan. Istilah makanan yang dihalalkan atau diharamkan, sering digunakan dalam al-Qur'an dalam pengertian umum, meliputi makanan dan minuman.

\section{Makanan Haram Dalam Islam}

Islam bukan hanya mengatur ibadah akan tetapi juga merupakan agama yang sesuai dengan akal manusia. Hal ini sesuai dengan beberapa ketentuan dalam islam yang dapat dibuktikan dengan penelitian maupun akal pikiran manusia seperti hukum halal dan haramnya makanan maupun minuman.

Allah SWT menghalalkan makanan dan minuman yang bermanfaat bagi manusia dan sebaliknya Allah mengharamkan makanan dan minuman yang membahayakan bagi manusia. Makanan dan minuman yang dikonsumsi seseorang dapat berpengaruh bagi jiwa seseorang dan mengganggu ibadah karena makanan dan minuman haram adalah salah satu perangkap setan untuk menjauhkan manusia dari Allah SWT.

Sebenarnya hukum asal makanan baik yang berasal dari hewan maupun tumbuhan, adalah halal berdasarkan firman Allah SWT berikut : 


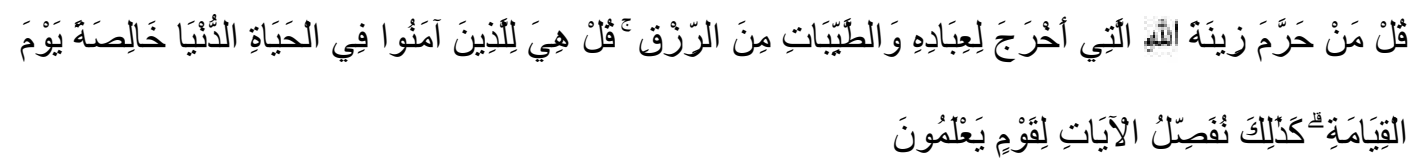

Artinya : Katakanlah (Muhammad), "Siapakah yang mengharamkan perhiasan dari Allah yang telah disediakan untuk hamba-hamba-Nya dan rezeki yang baik-baik ? Katakanlah, "Semua itu untuk orang-orang yang beriman dalam kehidupan dunia, dan khusus (untuk mereka saja) pada hari kiamat. Demikianlah kami menjelaskan ayat-ayat itu untuk orang-orang yang mengetahui." (QS. Al-Araf ayat 32)

Begitu juga yang dinyatakan oleh ulama imam Syafii berikut : "Hukum asal makanan dan minuman adalah halal, kecuali apa yang diharamkan oleh Allah dalam Al-Qur'anNya atau melalui lisan Rasulullah Karena apa yang diharamkan oleh Rasulullah sama dengan pengharaman (dari) Allah."

Adapun beberapa sebab suatu makanan dan minuman menjadi haram menurut Syekh Abu Malik Kamal Bin As-Sayyid Salim dalam kitabnya Shahih Fiqih Sunnah menyebutkan bahwa makanan dan minuman menjadi haram karena salah satu dari lima sebab berikut :

$>$ Membawa mudharat pada badan dan akal.

$>$ Memabukkan. Merusak akal, dan menghilangkan kesadaran (seperti khamar dan narkoba).

$>$ Najis atau mengandung najis.

> Menjijikkan menurut pandangan orang kebanyakkan yang masih lurus fitrahnya.

> Tidak diberi izin oleh syariat karena makanan atau minuman tersebut milik orang lain. Artinya haram mengkonsumsinya tanpa seizin pemiliknya.

\section{1) Jenis Makanan Haram}

Salah satu kaidah yang masyhur dalam urusan makanan adalah bahwa segala sesuatu hukumnya halal, kecuali yang disebutkan pengharamannya dalam al-Qur'an dan hadis Nabi. Oleh karena itu di sini akan disebutkan jenis-jenis makanan yang haram sebagaimana telah disebutkan dalam al-Qur'an dan al-hadis.

a. Bangkai

Yaitu hewan yang mati tanpa melalui proses penyembelihan yang syar'i. Dalil pengharaman bangkai adalah firman Allah dalam surah Al-An'am ayat 145 :

Artinya: Katakanlah : "Tidak kudapati di dalam apa yang diwahyukan kepadaku, sesuatu yang diharamkan memakannya bagi yang ingin memakannya, kecuali daging hewan yang mati (bangkai), darah yang mengalir, daging babi karena sesungguhnya semua itu kotor atau hewan yang disembelih bukan atas (nama) Allah. (QS. Al-An'am : 145)

Termasuk kategori bangkai adalah setiap hewan yang mati secara tidak wajar, tanpa disembelih secara syar'i, yakni :

- Al-Munkhaniqah, yaitu hewan yang mati karena tercekik

- Al-Mauqudzah, yaitu hewan yang mati karena dipukul

- Al-Mutaraddiyah, yaitu hewan yang mati karena terjatuh dari tempat yang tinggi

- An-Nathihah, yaitu hewan yang ditanduk oleh hewan lain lalu mati

- Hewan yang dimangsa atau diterkam oleh binatang buas. 
Jika suatu hewan mati karena salah satu dari kelima sebab diatas, maka haram memakannya. Kecuali jika masih hidup dan sempat disembelih, maka ia menjadi halal. Dalil larangan untuk hewan yang mengalami kelima kondisi diatas dijelaskan dalam surah Al-Maidah ayat 3 :

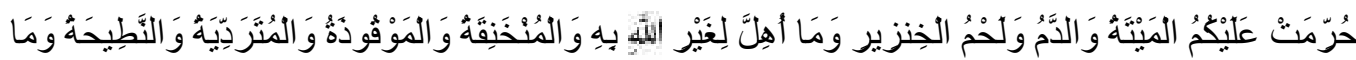

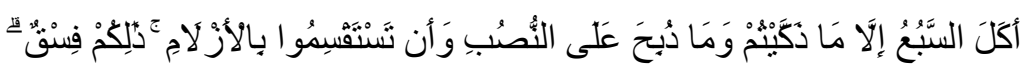

Artinya : Diharamkan bagimu (memakan) bangkai, darah, daging babi, (daging hewan) yang disembelih atas nama selain Allah, yang tercekik, yang terpukul, yang jatuh, yang ditanduk, dan diterkam binatang buas, kecuali yang sempat kamu menyembelihnya, dan (diharamkan bagimu) yang disembelih untuk berhala. Dan (diharamkan juga) mengundi nasib dengan anak panah, (mengundi nasib dengan anak panah itu) adalah kefasikan.. (QS. Al-Maidah : 3)

Ayat tersebut sekaligus menjadi dalil keharaman jenis makanan yang akan disebutkan selanjutnya. Dan adapun faidah-faidah dari penjelasannya yaitu :

Faidah (1) Termasuk bangkai adalah bagian tubuh yang terpotong dari hewan yang masih hidup. Maksudnya hewan tersebut tidak disembelih. Tapi hanya dipotong bagian tubuh tertentu saja, paha misalnya. Maka bagian tubuh yang dipotong itu termasuk bangkai dan tidak halal dimakan. Hal ini berdasakan sabda Nabi yang mengatakan bahwa, "Ma Quthi'a minal bahimati wa hiya hayyah fa huwa maytatun, Bagian tubuh yang terpotong dari hewan yag masih hidup termasuk bangkai". (HR. Abu Daud dan Ibnu Majah).

Faidah (2) Ada dua bangkai yang dikecualikan (tidak haram), yakni ikan (hewan laut) dan belalang. Dasarnya adalah perkataan Ibnu 'Umar radhiyallahu 'anhuma, "Telah dihalalkan untuk kita dua macam bangkai dan dua macam darah. Adapun dua macam bangkai adalah ikan dan belalang,. .”(Diriwayatkan oleh Ibnu Majah dan Ahmad).

Lalu bagaimana jika kita menemukan ikan atau hewan laut lainnya yang terapung di atas permukaan air ?, Apakah halal dikonsumsi atau tidak ?, Dalam masalah ini ada dua pendapat ulama. Namun yang paling rajih (kuat) adalah pendapat yang mengatakan kehalalannya. Kecuali jika terbukti secara medis bahwa ikan yang terapung itu sudah rusak dan membahayakan kesehatan atau mengeluarkan bau busuk, maka menghindari dan meninggalkannya lebih utama. Karena hal itu lebih selaras dengan kaidah syari'ah yang mengaramkan setiap makanan yang buruk dan menjijikkan.

b. Darah yang Mengalir

Tidak halal mengkonsumsi darah yang dialirkan atau ditumpahkan. Hal ini berdasarkan firman Allah pada Surah Al-Maidah ayat 3 dan Al-An'am ayat 146 :

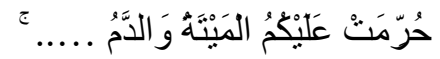

Artinya : "Diharamkan bagimu (memakan) bangkai, darah, ... " (QS. Al-Maidah ayat 3).

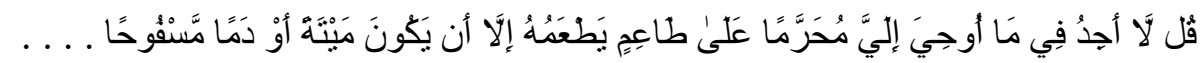

Artinya : “. . . kecuali kalau makanan itu bangkai, atau darah yang mengalir ...."

(QS. Al-An'am :146) 
Adapun darah yang sedikit semisal yang tersisa pada daging sembelihan, maka hal itu dimaafkan. Selain itu dikecualikan pula hati dan limpa, sebagaimana dalam atsar Ibnu Umar yang diriwayatkan Ibnu Majah dan Ahmad diatas, "Telah dihalalkan untuk kita dua macam bangkai dan dua macam darah. . . . Dan adapun dua macam darah adalah hati dan limpa." (Diriwayatkan oleh Ibnu Majah dan Ahmad).

\section{c. Daging Babi}

Berdasarkan firman Allah SWT. Dalam Surah Al-Maidah ayat 3 dan Surah Al-An'am ayat 146 :

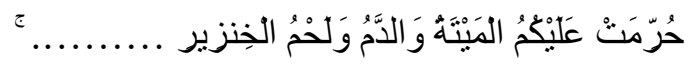

Artinya : "Diharamkan bagimu (memakan) bangkai, darah, daging babi, ..." (QS. AlMaidah : 3)

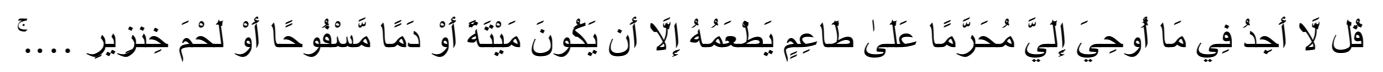

Artinya : “. . .kecuali kalau makanan itu bangkai, atau darah yang mengalir, daging babi, ..." (QS. Al-An'am : 146).

Penyebutan daging mencakup seluruh bagian tubuhnya, baik daging, lemak, tulang, rambut, dan sebagainya. "Tidak ada perselisihan diantara ulama tentang haramnya babi : dagingnya, lemaknya, dan seluruh bagian tubuhnya", demikian penegasan Penulis kitab Shahih Fiqih Sunnah. Ini termasuk dalam kaidah "dzikrul ba'dh yuradu bihil kull", Menyebutkan sebahagian, tapi yang dimaksud adalah keseluruhan. Jadi hanya disebutkan daging, yang dimaksud seluruh bagian tubuh babi. Karena biasanya yang dimakan dari hewan adalah dagingnya.

d. Hewan yang Disembelih Tanpa Menyebut Nama Allah atau Menyebut Selain Nama Allah

Dasar pengharamannya adalah dalam Surah Al-Maidah ayat 3 dan Surah Al-An'am ayat 121:

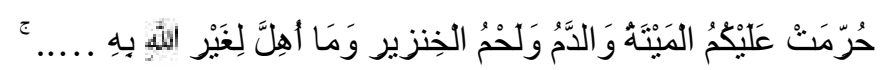

Artinya : "Diharamkan bagimu (memakan) bangkai, darah, daging babi, (daging hewan) yang disembelih atas nama selain Allah,...." (QS. Al-Maidah : 3)

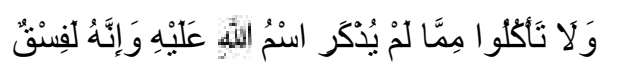

Artinya : "Dan janganlah kamu memakan -hewan-hewan- yang tidak disebut nama Allah saat menyembelihnya. Sesungguhnya perbuatan semacam itu termasuk kefasikan". (QS. Al-An'am : 121).

Oleh karena itu, tidak dihalalkan mengkonsumsi sembelihan orang kafir, orang musyrik, atau orang majusi. Sebab sembelihan mereka tidak sah karena tidak menyebut nama Allah. Adapun sembelihan Ahli Kitab boleh dimakan, selama tidak diketahui bahwa mereka menyembelih dengan menyebut nama selain Allah. "Dan makanan (sembelihan) Ahli Kitab halal bagimu, dan makananmu halal bagi mereka”.(QS. Al-Maidah : 5).

Bagaimana dengan daging dan makanan olahan dari daging yang diimpor dari negeri non Muslim ?, Ada tiga kemungkinan yaitu : 
$>$ Jika yang diimpor dari negeri non muslim berupa daging-daging hewan laut, maka halal dimakan. Karena hewan laut boleh dimakan tanpa disembelih, baik ditangkap oleh Muslim maupun non Muslim.

> Apabila yang diimpor adalah unggas dan daging hewan darat yang halal dimakan, seperti ayam, bebek, sapi, kambing, kelinci, dan sebagainya, maka dilihat negara asalnya. Jika berasal dari negeri yang mayoritas penduduknya menganut paham atheis, beragama majusi, penyembah berhala (kaum pagan), maka daging-daging dari negeri tersebut tidak halal.

Adapun jika berasal dari negeri-negeri yang penduduknya mayoritas penganut Yahudi dan Nasrani (Ahli Kitab), dihalalkan dengan dua syarat : Pertama, Disembelih secara syar'i (sembelihan ahli kitab halal dimakan), Kedua, Tidak diketahui, mereka menyebut selain nama Allah ketika menyembelihnya.

Akan tetapi sebagian negara eksportir yang biasa mengekspor ke negeri Muslim melibatkan ummat Islam dalam proses penyembelihan dan disembelih secara syar'i. Oleh karena itu jika ada pengakuan (yang telah dicek kebenarannya) dari negara pengekspor, bahwa hewan tersebut disembelih secara syariat, halal memakannya. Tetapi jika terbukti, dari berbagai temuan dan fakta yang ada, negara-negara tersebut tidak menyembelihnya menurut syari'at Islam, tidak halal dimakan. Adapun sekadar label halal atau tulisan "disembelih menurut syari'at Islam" yang tertempel pada kemasan daging tersebut, maka tidak dapat dijadikan standar.

$>$ Keju impor yang berasal dari negeri ahli kitab yang memproduksi keju dari lemak hewan yang halal dikonsumsi, maka boleh bagi kaum Muslimin memakannya. Tetapi jika mereka memproduksi keju dari lemak hewan yang haram dimakan seperti Babi, maka keju dari negeri tersebut haram dikonsumsi.

\section{e. Hewan Yang Disembelih Untuk Berhala}

Dasar pengharamannya adalah firman Allah dalam surah al-Maidah ayat 3 :

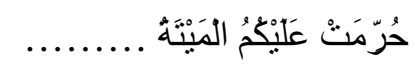

Artinya : "Diharamkan bagimu (memakan) bangkai, ... . Dan (diharamkan pula) yang disembelih untuk berhala". (QS. Al-Maidah : 3).

Ini mencakup semua binatang yang disembelih untuk kuburan, sesajen yang dilabuhkan ke laut, tumbal proyek pembangunan jembatan atau jalan, tugu peringatan yang disembah sebagai tanda dan simbol bagi sesembahan selain Allah, atau sebagai perantara kepada Allah. Hewan yang disembelih untuk berhala haram dikonsumsi meskipun disembelih dengan menyebut nama Allah. Jika tidak menyebut nama Allah saat menyembelihnya (misalnya menyebut nama berhala yang akan dituju), maka lebih haram lagi. Karena menggabungkan dua sebab keharaman sekaligus. Sembelihan atas nama selain Allah dan untuk selain Allah.

\section{Minuman Haram Dalam Islam}

Pada dasarnya semua minuman yang dikonsumsi manusia adalah halal namun dapat menjadi haram hukumnya disebabkan oleh kondisi tertentu. Minuman haram adalah minuman yang dilarang diminum oleh umat islam karena mudharatnya lebih besar dari manfaatnya. Minuman yang diharamkan dalam islam dapat dikarenakan sifatnya maupun dzatnya. Seseorang yang minum minumam haram tentunya berdosa dan dapat menyebabkan berbagai masalah. 
Minuman tersebut haram dikarenakan beberapa sebab diantaranya adalah :

- Dikonsumsi secara berlebihan dan Allah SWt tidak menyukai hal-hal yang melampaui batas.

- Memabukkan dan dapat menghilangkan akal atau kesadaran seseorang.

- Termasuk zat najis atau kotoran yang diharamkan.

- Merupakan hak orang lain yang tidak boleh diminum sembarangan tanpa izin orang yang memilikinya.

- Menjijikkan dan tidak sepantasnya dikonsumsi oleh manusia.

- Mambahayakan kesehatan maupun nyawa manusia jika dikonsumsi

\section{1) Jenis Minuman Haram}

Berikut ini adalah minuman-minuman yang diharamkan dalam islam :

a) Minuman yang berasal dari darah

Darah adalah salah satu jenis makanan atau minuman yang diharamkan untuk diminum. Seperti halnya beberapa orang yang gemar minum darah binatang seperti ular dan sebagainya dengan alasan kesehatan atau untuk menyembuhkan suatu penyakit. Hal ini sesuai dengan firman Allah SWT dalam ayat berikut ini :

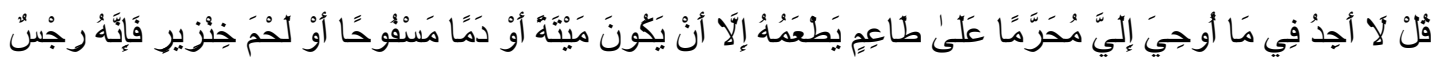

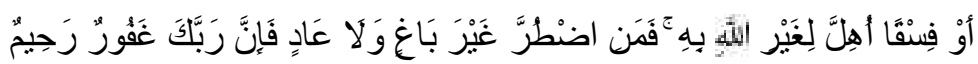

Artinya : Katakanlah, "Tidak kudapati di dalam apa yang diwahyukan kepadaku, sesuatu yang diharamkan memakannya bagi yang ingin memakannya, kecuali daging hewan yang mati (bangkai), darah yang mengalir, daging babi karena sesungguhnya semua itu kotor atau hewan yang disembelih bukan atas (nama) Allah. Tetapi barang siapa terpaksa bukan karena menginginkan dan tidak melebihi (batas darurat) maka sungguh, tuhanmu maha pengampun, maha penyayang. (QS. Al-An'am : 145).

b) Minuman keras atau khamar

Minuman keras yang dimaksud dalam jenis minuman ini adalah minuman yang mengandung alkohol dan diharamkan dalam islam segala minuman yang memabukkan. Sebagaimana yang disebutkan dalam hadis Nabi :

Artinya : "Semua yang memabukkan adalah khamar dan semua khamar adalah haram." (HR. Muslim)

c) Minuman yang diminum dalam bejana emas

Umat islam dilarang meminum minuman yang diletakkan dalam bejana emas karena ini adalah satu bentuk hal yang berlebih-lebihan dan perilaku orang kafir sehingga Allah tidak menyukai hal tersebut. Sebagaimana yang disebutkan dalam hadits berikut ini : Artinya : "Janganlah kalian minum dengan bejana yang terbuat dari emas dan perak dan jangan pula kalian makan dengan piring yang terbuat dari keduanya. Karena barangbarang tersebut adalah untuk mereka (orang-orang kafir) ketika di dunia.” (HR Bukhari)

d) Minuman yang membahayakan diri

Minuman yang membahayakan diri adalah minuman yang dicampur racun atau zat yang dapat membahayakan nyawa misalnya saat seseorang meminum racun dan mencoba menyakiti dirinya sendiri atau melakukan usaha untuk bunuh diri sementara perbuatan 
tersebut dikutuk Allah SWT. Seperti yang disebutkan dalam hadits berikut ini : "Tidak boleh melakukan perbuatan yang dapat membahayakan diri sendiri dan orang lain".

e) Minuman yang diambil dari orang lain tanpa izin

Minuman yang diperoleh dari mencuri atau menipu atau minuman yang dibeli dengan harta yang tidak halal seperti harta korupsi atau riba adalah haram diminum meskipun minuman tersebut dzat asalnya adalah halal. Seperti yang disebutkan dalam Al-Qur'an berikut ini : "Wahai orang-orang yang beriman! Janganlah kalian saling memakan harta sesama kalian dengan jalan yang batil (tidak benar). ..” (QS. An-Nisa : 29)

f) Minuman yang mengandung zat yang diharamkan

Yang dimaksud dengan minuman yang mengandung zat yang diharamkan seperti darah, air liur anjing dan sebagainya misalnya saja minuman kesehatan atau jamu yang dicampur dengan darah binatang atau minuman yang dicampur dengan alkohol.

g) Minuman yang tercampur najis

Najis adalah kotoran dan minuman yang mengandung najis haram hukumnya untuk dikonsumsi oleh umat islam. Semua hal yang najis haram hukumnya seperti darah dan bangkai namun segala yang haram belum tentu najis misalnya ganja atau obat-obatan terlarang.

h) Minuman dengan efek psikotropika

Minuman dengan zat psikotropika atau minuman yang dicampur dengan obat bius dan lainnya, haram hukumnya untuk dikonsumsi karena dapat menghilangkan akal dan kesadaran dan efeknya sama seperti minuman keras yang menyebabkan kecanduan.

i) Minuman yang dianggap memiliki kekuatan

Minuman yang dianggap memiliki kekuatan misalnya minuman yang telah diberi jampijampi atau mantra dari seseorang yang dianggap orang pintar atau paranormal. Minuman tersebut haram hukumnya karena termasuk dalam perbuatan syirik dan mempercayai hal-hal yang sifatnya musyrik meskipun minuman tersebut ditujukan untuk menyembuhkan suatu penyakit.

Demikian penjelasan mengenai minuman haram dalam islam dan sebab-sebab diharamkannya. Allah SWt telah menghalalkan makanan dan minuman yang memberik manfaat bagi manusia terutama umat islam untuk itulah kita sebagai umat islam sepantasnya menjaga diri kita dari makanan dan minuman yang haram.

\section{PENUTUP}

\section{Kesimpulan}

Dalam bahasa arab makanan berasal dari kata al-tha'am dan jamaknya Al-Atimah yang artinya makan makanan. Sedangkan dalam ensiklopedi hukum Islam makanan ialah segala sesuatu yang boleh dimakan oleh manusia atau sesuatu yang menghilangkan lapar. Dalam bahasa arab minuman berasal dari kata al-asyribah dan jamaknya al-syarb yang artinya minum minuman. Sedangkan dalam ensiklopedi hukum islam diartikan dengan jenis air atau zat cair yang bisa diminum. 
Hukum Islam melalui al-Qur'an dan hadis telah menetapkan beberapa jenis makanan dan minuman yang haram dikonsumsi umat Islam, antara lain bangkai, darah, babi, binatang yang disembelih dengan menyebut nama selain Allah, serta khamar dan semua jenis minuman yang memabukkan. Sedangkan makanan dan minuman yang tidak disebutkan sebagai makanan dan minuman haram dalam al-Qur'an dan hadis, dan tidak menjijikkan atau membahayakan kesehatan (jiwa) manusia maka bisa dikategorikan sebagai makanan dan minuman yang halal.

2. Saran

Diharapkan perkembangan ilmu yang pesat di zaman modern ini tidak luput dari nilainilai agama dan agama dapat dijadikan arah dalam menentukan perkembangan ilmu selanjutnya. Tanpa adanya bimbingan terhadap ilmu dikhawatirkan kehebatan ilmu dan teknologi tidak semakin menyejahterakan manusia, tetapi justru merusak bahkan menghancurkan kehidupan mereka.

\section{DAFTAR PUSTAKA}

Arsyam, M., \& Alwi, A. M. (2020). MANAJEMEN HIDUP DALAM PERSPEKTIF AL-QUR'AN. [10/1 15.20]

Yanggo, Huzaemah Tahido. "Makanan dan Minuman Dalam Perspektif Hukum Islam." TAHKIM 9.2 (2017).

Arsyam, M. (2020). Manajemen pendidikan islam. [10/1 15.19]

Zulaekah, S., \& Kusumawati, Y. (2005). Halal dan haram makanan dalam islam.

Makmur, Z., Arsyam, M., \& Alwi, A. M. S. (2020). Strategi Komunikasi Pembelajaran Di Rumah Dalam Lingkungan Keluarga Masa Pandemi. KOMUNIDA : Media Komunikasi dan Dakwah, 10(02), 231-241.

Al-Qaradhawi, Yusuf, and Mohd Hafiz bin Daud. Halal dan haram dalam Islam. PTS Publishing House Sdn. Bhd., 2016.

Ahmad, H., \& Arsyam, M. (2020). ETIKA PERDAGANGAN DALAM ISLAM.

Arsyam, M. (2021). BAHAN AJAR ADMINISTRASI PENDIDIKAN. [10/1 15.20] 